\title{
Language and Power Nexus: A Critical Study of Pakistani Political Discourse
}

\author{
Ayyaz Qadeer ${ }^{1} \&$ Wasima Shehzad ${ }^{2}$ \\ ${ }^{1}$ Department of Management Sciences, COMSATS Institute of Information Technology, Wah Cantt., Pakistan \\ ${ }^{2}$ Faculty of Social Sciences, Air University, Islamabad, Pakistan \\ Correspondence: Ayyaz Qadeer, Department of Management Sciences, COMSATS Institute of Information \\ Technology, Wah Cantt., Pakistan. E-mail: ayazqadeer@yahoo.com
}

\author{
Received: September 30, 2017 Accepted: October 22, $2017 \quad$ Online Published: December 23, 2017 \\ doi:10.5539/ijel.v8n2p207 \\ URL: http://doi.org/10.5539/ijel.v8n2p207
}

\begin{abstract}
The present study presents a critical view of the speech delivered on May 09, 2011 by the prime-minister of Pakistan, Yousuf Raza Gillani. Following the language of the political discourse, this speech is delivered in the parliament house in front of the speaker, but is meant for the masses. The position of the speaker remains uniform as the questions are asked in the end alone. However, the speech is meant for both the addressee present at the time of the speech, and the assumed masses. It was found out the pronouns we, our, were constantly used to shift the responsibility on Al-Qaida whereas "I" was used for authority in order to digress the discussion from the topic. The pronouns and the vocabulary together establish the in-group or out-group category. The solidarity is shown towards the masses to get their support and defense is shown towards the allies who are accusing the government of fraud and nefarious ploy. Mystification is performed at a number of places to hide truth and claim the truth alternatively.
\end{abstract}

Keywords: Osma Bin Laden, political discourse, lexical choices, US operation

\section{Introduction}

Political discourse is all pervasive and influential due to its strong power to access the public at large. It generates the influence on the public perception, and, due to the political support of the system, they assume the power of representing the public sentiments. In this regards, the important events are properly shaped through the political discourse to present before public as their views.

A lot of events that were against the popular set political narratives, occurred in Pakistan in the previous decade, and they got the international importance. The occasion of the Abbottabad operation by US in which Osama Bin Ladin was murdered, is one such event where this conflict of a popular narrative, that Pakistan is against Al Qaida, and the presence of its leader in Pakistan, was publically addressed by the Prime Minister of Pakistan, Syed Yousuf Raza Gilani, on May 09, 2011 in the parliament (please see appendix for original speech). This study is an analysis of that speech to see how certain linguistic features have been used to take people in confidence with the help of the most important political position. A critical approach has been used to analyze this speech and some features of critical discourse model presented by Norman Fairclough have selected to look closely into the text.

\section{Political Discourse and Its Role in Power Structures}

Language, as a matter of fact, is an influential instrument for the creation of reality; it facilitates listeners and readers to construct a meticulous vision of that reality. Language of the politicians, in this framework, assumes a critical role in acquiring the favors and the endorsement of the public. The political leaders either deliver speech within a nationwide framework or in public background, either they are in government or they are out of it, try to exploit and maneuver language through rhetoric. Politicians opt this approach for political gain and power. As they sense most often, they are incapable to convince; they require building up consent so as to execute their own agendas. As a result, they develop this consent with the practice of a peculiar sort of discourse. Actually, cultural practices give birth to discourse which is constructed through the linguistic self consciousness of listener and the speaker. Media plays a critical role in this regards (Kelly-Holmes \& Milani, 2013). The speaker uses firm techniques through discourse to build the image and utilizes the concealed ideologies of the listeners that are 
shared cultural practices.

Post-structuralist linguists reject the idea that language is neutral and transparent means to represent the social realities. They are of the view that it is exercised to create identity and ideology, production of knowledge and its reproduction, and power relations and community relations. It is also exercised through institutional control and through their hegemony.

However, the discourse analyst uncovers the embedded intentions through the analysis of the surface meaning along with the implicit meaning. As a matter of fact, the purpose is to create profound understanding of particularly what is not said along with what is said. All this is analyzed with the view that whose purpose is being served and what are the intentions behind it. No text, in critical analysis, can be analyzed outside its context. It is argued that context plays a pivotal role in providing a specific meaning to the text, written or spoken. Therefore, Mautner (2008) is of the view that language is biased to convey meanings, and they are always mediated. Political speeches are very much part of this type of discourse.

Foucault (1973) raised the question of the ways in which knowledge along with power go through in some kinds of practices, for example, the instruction of the governing bodies, and construction of the identity. As a result, it focuses how the persons desire to manage themselves. Foucault gives attention to those practices which are used to exercise power over people influencing the behaviour and mind.

The concept of the order of discourse, the distinction between internal relations within an order of discourse and external relations between orders of discourse, allows us to focus upon the field of politics with its discursive aspect. On the one hand, we might describe the order of discourse of professional politics, political communication and struggle between professionals, as it manifests itself in parliament, political meetings and discussions. One concern here would be to specify the structured set of political discourse so that on could see more clearly how the discourse was located within the internal relationships of the order of discourse. On the other hand, we might describe external relations between the political order of discourse and other orders of discourse. Moreover, discursivity has always been added in the political discourse through media reflection (Fetzer \& Lauerbach, 2007).

Fairclough (1989) has asserted that discourse is featured prominently with one of its capacities and that is its potential to build a position of a subject for the "ideal subject". It is due to this feature that the real readers are induced to negotiate a relationship with this idealized subject. He has spoken about the hidden power of political discourse that it has the ability to restraint content and, therefore, it favors particular version of interpretations to present the event.

Public discourse is a type of discourse through which limited members of society have access to the public, and, through this access and approach, they can convey their beliefs, ideas, and intentions through discourse. In other words, they can influence the public at large. For this, they use resources to approach the public. According to van Dijk (1997), one of the most important resources is the approach to public discourse, and it is a resource that is shared by representatives of elites, for instance, politicians, writers, intellectuals, columnists, teachers, and many more. It is an obvious fact that individuals require to approach public discourse either it is through text or talk to influence public at large. Some of these forms can be parliamentary discussions, news stories, articles, books, editorials, work of fictions, TV shows, advertisements, and so on. Consequently, control of the powerful in the form of some groups or institutions is established.

The power of various institutions in society, and how they uphold their control all the way through the language employment, has been an issue of deliberation among the scholars. In this context, van Dijk (1997) provides a view that public discourse is a tool for the social reproduction of power. He further adds that politicians exert, through public discourse, their political power on one hand and on the other, they substantiate and reproduce political power through public discourse. In this context, it should be kept in mind that political discourse is the major source of shaping opinion of general public. Fairclough (2001) is of the opinion that only those who have the ability to shape the public opinion can approach the power structures.

Politics, primarily, is associated with people and with their lives in organized communities, and the traditional party politics is so beyond this arena. Politics is a social activity like so many in a civilized society. It has a specific code, and the language used in a political discourse has specific features. This type of discourse as one of political rituals needs more attention. As a matter of fact, the work to find out connection between language and power started few decades ago; however, the critical angle to study it is not that much old (Beard, 2001). The way the language reflects the ideological position of politicians and how the readers' ideological position is generated and affected is very important. 
Generally, Politics plays an important role in our lives. Likewise, Fairclough (1989) is of the view that politics, to some extent, can be traced in the disputes and struggles occurred in language and over language. Additionally, politics is carried out either through political discourse or through diverse genres of political discourse, for instance, political speech, parliamentary debates, media interviews and shows, and political advertising (van Dijk, 1997). Finally, politics and political discourse are mingled in public sphere, and both affect presentation of the participants who are politicians, and recipient of political discourse that is public.

As it is the concern of the present study, a political speech, being a political genre, more often is used to perform politics. It can also be used as an object of the analysis to see the hidden agenda behind the statements of the speakers since language in political speech can control and influence political action and trust of the audience (van Dijk, 1997). Political speech is one type of discourse which produces and reproduces beliefs, opinions, and ideologies (Wodak, 2004). In other words, political speech must have certain ideology to be spread among the audience. The role of propagation of discourse on the perception of the audience is critical in present time, and its manifold dimensions need proper attention (Riley, 2005).

In view of politics and politicians, Bourdieu's (1991) view is thought to be one of the earliest works in terms of their use of language and in terms of creation of political discourse. It is pertinent to discuss a few of his views in the present context. According to him, proficient organizations dealing in politics have a different life, and gradually disconnect those whom they represent. The sense of overall political discourses and the political stances is the most prominent learning in the training process of a politician. This sense enables a politician to deliver a proper political discourse. Bourdieu gives this sense a name of political habitus. Moreover, politicians produce a discourse which is doubly determined. Firstly, it is internally determined by its position in politics, and secondly, it is externally determined by its connections to the fields other than politics. The latter is more concerned with the people's lives and efforts, which they represent. Politicians endeavor to win their trust and support (Fairclaugh, 1995).

The above arguments of the linguists provide a platform to connect political discourse with the power generated in discourse. Fairclaugh (1995) argues that political discourse reproduces or alters the community by reproducing or changing representation of people through discourse. Furthermore, political discourse demonstrates the strong bond between ideational and interpersonal practices in discourse (Bourdieu, 1991). In other words, it has the potential to replicate or modify the society solely through reproducing and changing classes and groups in society. It works on representations as well as classifications of reality along with representations and classifications of the concerned people (Fairclaugh, 1995). In short, the power of discourse in politics relies on its potential to form and activate social factors that have capacity to carry out promised reality into a new reality.

\section{Method}

The present study is qualitative in nature. Creswell (2013) points out that qualitative data and its analysis include many phases together like its organization, reading, describing, classifying and interpretation. Similarly, Merriam (2009) is of the opinion that qualitative research starts data collection and it analysis at the same time.

Moreover, post-structuralist discourse analysis (PDA) unmasks the text by analyzing the surface meaning and implicit meaning, hence, giving a different perspective. The purpose of PDA is to develop deeper understanding of what is said and what is not and whose interest is served and for what purposes. For the purpose of critical analysis, no text can be studied without its particular context as it is the context that gives particular meaning to a particular text whether it is written or spoken. In the post modern and post structural perspective, language is not a neutral means for conveying things but language is always mediated. It is more acute and meaningful regarding political speeches.

To uncover the hidden intentions that are embedded in the text through the already established political and social ideologies, the most striking event of US operation in Abbottabad, Pakistan, on May 02, 2011, has been selected, and the political speech delivered by the, then, Prime Minister of Pakistan on May 09, 2011, in the parliament as a first response after the event, has been analyzed in the next pages (please see Appendix for original speech).

For the analysis of a political speech, some features from Norman Fairclough's model of discourse analysis have been selected. Being a renowned figure in CDA, he presents the three dimensional model of the analysis of the text to view it critically. The perspectives of lexical choices, lexical options, modalities, placement and nature of arguments, subject position and its power relation in the text in terms of its relational, experiential and expressive values have been analyzed in the speech text. 


\section{Results}

The speech delivered by the Prime Minister of Pakistan, after the Abbottabad "incident" of the May 02, 2011, was the first official response of the govt. of Pakistan. Following the language of the political discourse, this speech is delivered in the parliament house in front of the speaker, but is meant for the masses. The position of the speaker remains uniform as the questions are asked in the end alone. However, the speech is meant for both the addressee present at the time of the speech, and the assumed masses. Therefore the speech gets complicated as the presence of hearers has to be kept intact. In the political speech, the discourse is diverse and also indeterminably composite; therefore, the speaker has to set up a subject position for an ideal listener.

This speech is addressed in the Pakistani parliament within a meticulous political context. Therefore, diverse parts of the language analyzed have been uttered with definite implicit ideological assumptions and power relationships. As a matter of fact, this speech has a usual discourse which shows the decorum of the parliament with the insistent reiteration of "honorable speaker". It provides the notion of the etiquette specific to the parliament and the power of the institution behind it. This parliament is dominated in number by the members of the speaker's party; however, opposition members are also an audience. The speech uses personal pronouns which have been used in abundance. They are the strongest indicators to demonstrate how the contents are employed for the exploitation of the common view.

The political, cultural and historical environment in this speech has been set in some of the terminologies which assist to construct the desired form of reality. As it is a purpose of a discourse to create reality, evidences to shape certain perspective have been indentified in the speech. Silence is very much important in the analysis of discourse, and here, the voice of the others in the discourse is absent. Their presence in the form of clapping is also significant.

\subsection{Position of the Speaker}

The ideal listener in a political discourse is the ordinary citizen. The assumed position of the speaker is set up with the assumed listener in such a way that the speaker shares his beliefs, ideas, and feelings through his discourse. The discourse also establishes the subject position amidst the discourse norms.

The speech is delivered in English which is the second language in Pakistan. In a way the speaker has already distanced himself from the masses of the general public. The language has brought the speaker closer to the international media and all those who could understand this medium. What relational values do textual features have? Are there inconsistencies in relational values which could indicate a new articulation of discourse types?

Subject position of a speaker of a political discourse is constructed not as an individual, but on the basis of the political party's agenda. Hence, the subject position has a social basis which is constructed by the party by wielding diverse social groups together through the agenda, and minimizes the cancels of coalition. The speaker of this speech is a representative of the party of the masses; .the party claims to be constituted on the ideological framework of the masses: the middle class, the working classes and the poorer class. This speech is placed at a point where the party is in drastic conditions, and, with a threat of a Marshal Law looms large, the party needs support of the masses. The speaker structures his position and restructure it for the masses specially those who are a victim of political discourse. This speech is targeted for the members of the parliament including the opposition party and the masses. The speaker is essentially projecting his ideas, expectations and stance into the audience as to let them comply with his viewpoint. One important aspect of this technique is that it is done implicitly - in a way that the speaker constitutes himself as a representative of the people. This kind of an assertion has been claimed by the use of questions, noun phrases, coordination, and subordination clauses.

\subsection{Pronouns}

The speakers has used the pronoun "we" in many lines. This pronoun assimilates the speaker with the listeners in an exclusive way:
a. "We are a proud nation"
b. "We are all united and fully committed"
c. "We opened our house and homes..."
d. "We have an ongoing multitasking system"

These lines are potentially ambiguous. It is not really clear as to who is claimed as "we". This inclusive technique encompasses many people into the group, but at the same time it is characterized by mystification as the idea of collective union of people as united and committed is a truth claim which hides many other motives. One could suffice to say that the use of "we" is a technique to create an effect of exaggeration so that the 
listeners may hold the subject position as him. In some of the lines e.g., "we didn't not invite Al-Qaeda", it is not clear whether collective refers to the speaker (the government, ministers,) or the listeners and the masses in general. This ambiguity lets the speakers shift the responsibility off form their shoulders. The use of "we" suggests that the Al-Qaeda came into the territory of Pakistan without seeking any permission. However, it is quite evident that no terrorist forces can enter into a country without prior allowance. If it does, it is surely invading the autonomy of the country. The ambiguity also suggests that the entrance of Al-Qaeda was "somebody else's" idea. The assimilation of idea created through "we" suggests a separatist attitude between the government, and the other powerful agencies.

The pronoun, "our", is also used to show collective union of idea. However, alike "we" that suggests the subject, "our" suggests possession: "Our nation has met these challenges with supreme confidence." This pronoun suggests a sense of procession, but it also assimilates the speaker adopt the union with the struggling people who faced the challenges with an embracing attitude. The speaker is assimilating himself with the people. The direction of the assimilation is towards the masses or the sacrificing people. The pattern of the usage of personal pronoun, "I", in the speech shows that the speaker has claimed his subject position as a powerful and dominating status, someone who is the representative of the government.

The pronoun, "you", is used as an indefinite pronoun generally to refer to people; "As you know, there has been a sea-change in our relations with Afghanistan." It is an effective pronoun to talk about ordinary people. "You" is helping to create solidarity among people on one hand, and commonality of experience on the other in working class discourse. "You" is at times used to refer to oneself subtly. It is a way of positioning oneself in the center of self-same interests. When the speaker uses this pronoun he claims solidarity with the working class to show himself as one with the people. In case of this speech the sentence e.g., "I would like to inform you about my visit to France which I undertook on 3rd May.....", the pronoun stabilizes the structure of the speaker in the center, talking to a person not known. At the same time the interaction becomes one to one.

\subsection{Lexical Choices}

The use of vocabulary is specific to the context of the topic under discussion. At the same time the specific use of jargon brings complexity to the meaning. The speaker enters into a discourse to create familiarity to the listeners. However, the words are representations of ideologies of people and institutions. They have been constituted on three levels: use of jargons specific to topic, knowledge of the listeners, and intentions of the speaker. In this particular text some examples of specific use of vocabulary are: "confidence", "relations", "close", "friendly", "cooperative", "solidarity", "sacrifice", "consultations", "stakeholders of security" "reaffirmation", "bygone era", "war against terrorism" etc.

The speaker uses language to create an oppositional effect. Some words like "solidarity" and "sacrifice" are repeated, which help to construct a victim's ideology- an ideology of a developing country and people who are subordinated by the sheer power due to being a less powerful country. This creates a less powerful position. In the discourse between dominant and subordinated speakers, this technique offers ambiguity or implicit idea. It arouses sympathy to avoid the blame hurled at the speaker. This is clearly a discourse of a speaker who is standing on a weak ground and is using words as a defensive strategy. The phrase like "bygone era" is a technique of intensifier. It creates emotional quality of the words. In this way the intensifier often suggests a feeling to avoid the intensity of the real issue to the listener. The topic gets encompassed in the emotional discourse as the conscious filters concentrate on the feeling alone.

The vocabulary also ventures into the domain of focus object. The technique focuses attention on the object of the sentence rather than the subject. The shifting of the attention helps to emphasis the de-centralization of the subject. For example, the sentence, "drones are given out as an instrument to fight terror", carefully omits the subject. Hence, the object is acting as the subject. The phrase "drone attacks" is a highly sensitive issue. The implications attached to this issue are rather complex since the masses cannot ascertain as whom is the enemy / terrorists who create anarchy in the state: is it the terrorist agents in Pakistan, is it the agents themselves want to eradicate the terrorists, or is it the poor innocent citizens? Furthermore, the speaker avoids marking the decision -makings agents who has given permission for the eradication of terrorism. Therefore, whenever the speaker has to talk about the decisions, the object is brought into focus. Similar issue can be identified in the following sentence: "In fact, for the first time, our armed forces were deployed in the Torah Valley to form a Security cordon to interdict Al-Qaeda during the Tora Bora bombings."

Vocabulary and pronouns set the tone of the speech. The assertion about the people stables the position between the speaker as the leader and the listeners as the less powerful. He is a political leader and the representative of the government, but the speaker establishes his authority implicitly rather than explicitly due the sensitivity of 
the issue. By doing so, the technique of categorization is employed between different groups of people - the attackers, as a part of the international intelligence forces, and defenders or the victims, as the Pakistanis. Therefore, distance is created between these two groups. However, the distance is reduced between the masses and the speaker because the speaker intends to have the support of the masses. The pronouns and the vocabulary together establish the in-group or out-group. The solidarity is shown towards the masses to get their support, and defense is shown towards the allies who are accusing the government of fraud and nefarious ploy. Mystification is performed at a number of places to hide truth and to claim the truth alternatively. Hence the formulated position of the listener, speaker, and the masses change, and so does the social identity.

\subsection{Modalities}

Assertion of truth cannot be complete without a reference to the modalities. Modalities are of two types: expressive modalities and relational modalities. Modalities are associated with the speaker's or listener's authority. In the case of the speaker's authority, it deals with the truth claim and its representation. This is called as the expressive modality. If an authority of one person is maintained against many, we call it the relational modality. Modalities are usually maintained with the help of modal auxiliaries, like may, might, must, should, can, cant, ought to etc. Other grammatical features that assist in maintaining modalities are tense and adverb:

a. "We must assume full ownership and responsibility for realizing our shared vision of stability and prosperity." [Relational modality]

b. "I must say that this endeavor has found resonance and we are well on the road towards giving this vision tangible form." [Expressive modality]

c. "With India we are embarked on an important process of engagement that should yield dividends for our two peoples and for peoples of South Asia, as a whole." [Expressive modality]

d. "Pakistan alone cannot be held to account for flawed policies and blunders of others."

e. "Hiding in plain sight, as is evident in this case, is perhaps another technique that could be attributed to Osama Bin Laden in the realm of asymmetrical Intelligence." [Expressive modality]

$A$ is a part of the relational modality since the speaker is assuming the role of participant against the war on terrorism. The word must emphasize the need to be responsible so that each one of us can make this country a better place. The speaker as a participant holds each listener responsible so that his power and authority may implicitly be claimed. However, the use of "must" actually helps him acquire all the power to make him one who is in a position to impose orders on people. The sentence is a good example of contestation of ideology and ideological struggle.

The close examination of the expressive modality reveals an interestingly discursive structure through modals. In $b$ and $c$ parts, there is a possibility of constructing an action-oriented solution. It gives a tangible meaning to the problems marked earlier. This has been done because the realization of an ideal state and ideal accounts of the world, and its descriptions provide a comforting space to the listeners amidst such a canalized issue. The confessions of authority are, however, inconsistently shown in sentence $d$. Instead of encountering the issue with full throttle, the speaker is complying with a defensive strategy to one as not guilty. It seems as if the speaker is pleading as a guilty party. It is a concession to the speaker's position as the one to be guilty.

\subsection{Argumentation}

The arguments placed in the speech do not show that they have been given by the representative of a country whose autonomy and sovereignty has been violated but by a person who is giving explanations and excuses on what had happened:

a. "Pakistan is not the birth place of Al-Qaeda. We did not invite Osama bin Laden to Pakistan..."

b. "The war against terrorism is our own national priority"

c. "Our patriotic citizens and State institutions are all united in their resolve to prosecute this campaign against terror to its logical end. We will utilize all means and resources and In Sha Allah succeed."

d. "Blame games serve no purpose."

e. "There are no differences among the State institutions"

The above are few of so many arguments that show the direction of the whole speech as an excuse. In the whole speech there are only a few sentences with a mild intensity that US violated Pakistan's sovereignty. The major chunk of the speech is a try to show how cooperative and productive Pakistan has been throughout in last forty years. This time period refers to Afghan "Jihad" against Russian invasion when "Jihadi" camps were established 
everywhere in Pakistan with The US support. It is needless to mention here that it was cold war era. Usama Bin Ladin emerged from that "Jihadi" culture. With this background understanding, US launched a war against terrorism after 9\11, and Pakistan joined the coalition as frontline ally. Suddenly on May 02, 2011, US operated within Pakistani territory and found Osama, a fact always denied by Pakistan about his presence. On the other hand, US aggressively entered Pakistani territory without permission/prior intimation and operated in Abbottabad: an obviously embarrassing situation for Pakistan.

The arguments selected for this critical situation give the impression that the whole discourse is an explanation of what had happened, and not a factual or pragmatic stance on the event. With this series of arguments and their placement in the speech like "the reiteration of democracy", "parliament", "the will of people", "national consensus" and the expressions like "our real strength is our people" support the view that there are a lot intercrossing arguments making the whole speech not that convincing.

\section{Discussion}

As it was a qualitative research over a political speech on a critical situation of Abbottabad operation, the study shows various significant clues of power structure on various levels. First of all the preference of English language over Urdu has created a distance between the speaker and the audience, and it was written which means the whole exercise was a deliberate effort. Secondly, ambiguity through the use of personal pronouns has been created to deemphasize the entrance of Al-Qaeda as "somebody else's" idea. The assimilation of idea created through "we" suggests a separatist attitude between the government, and the other powerful agencies. Importantly, the speaker has tried to assimilate himself with the masses or the sacrificing people. In other words, assimilation has been tried not in the native but in a language less understood by the people of Pakistan. Furthermore, The pattern of the usage of personal pronoun, "I", in the speech shows that the speaker has claimed his subject position as a powerful and dominating status, someone who is the representative of the government. On the other side, "you" is helping to create solidarity among people on one hand, and commonality of experience on the other in working class discourse. As far as vocabulary issues are concerned, lexical choices representing ideologies of people and institutions have been used on three levels: use of jargons specific to topic, knowledge of the listeners, and intentions of the speaker. Some words like "solidarity" and "sacrifice" are repeated, which help to construct a victim's ideology- an ideology of a developing country and people who are subordinated by the sheer power due to being a less powerful country. Lexical choices with emotional quality have been used to avoid the intensity of the real issues.

It has been observed that on key issues, employment of passive structures shows the shifting of the attention to emphasize the de-centralization of the subject. The other important issue raised during the analysis was categorization. The speaker establishes his authority implicitly rather than explicitly due the sensitivity of the issue, and, for this, the technique of categorization has been employed between different groups of people. Moreover, mystification has been performed at a number of places to hide truth and to claim the truth alternatively. Modalities, in some places, help him acquire all the power to make him one who is in a position to impose orders on people. Mostly, they have been used to weaken the factual intensity of the event.

The study of the placement of the arguments presented by the speaker reveals some more facts. Instead of encountering the issue with full throttle, the speaker has complied with a defensive strategy. In the whole speech there are only a few sentences with a mild intensity that US violated Pakistan's sovereignty. The arguments placed in the speech do not show that they have been given by the representative of a country whose autonomy and sovereignty has been violated but by a person who is giving explanations and excuses.

\section{Conclusion}

The speech analyzed in the above lines is a traditional speech of political elite quite conscious of its power and position maintained through the use of different techniques. First of all, distance has been created by speaking English instead of Urdu that he used to speak delivering almost all of his political speeches. The personal pronouns have been used to proclaim that power, which perhaps was very difficult to acquire in such a difficult political position. Different linguistic techniques like modalities, subject positions and lexical choices with full of political ideologies have been used to persuade people's mind on one hand, and on the other, the implicit messages having varied hints for the international political forces over the Abbottabad incident, were incorporated in the speech.

The power in arguments is a try to overshadow the difficult political situation by highlighting some other symbols of power. It was only with the analysis of the nature of arguments and their placement that the intensions of the speech seem clear. The whole speech tends to be an excuse or an explanation of all that happened. Instead of asking for explanation and reasons for attack and international violation of boarder cross, 
this speech assumes a discourse of a guilty conscious that tends to express its obedience and loyalty, in the past years, to be considered higher than that just happened unfortunately.

\section{Reference}

Beard, A. (2001). The Language of Politics. London: Routledge.

Bourdieu, P. (1991). Language and Symbolic Power. USA: Polity Press.

Creswell, J. W. (2013). Qualitative Inquiry and Research Design: Choosing Among Five Approaches. London: Sage.

Fairclough, N. (1989). Language and power. London: Longman.

Fairclough, N. (1995). Critical Discourse Analysis: The Critical Study of Language. London; New York: Longman.

Fairclough, N. (2003): Analysing Discourse. Textual Analysis for Social Research. London: Routled.

Fetzer, A., \& Lauerbach, G. (2007). Political discourse in the media: Cross-cultural perspectives. Amsterdam: J. Benjamins Pub. Co. https://doi.org/10.1075/pbns.160

Foucault, M. (1973). Madness and civilization. Translated by Richard Howard. New York: Random House.

Kelly-Holmes, H., \& Milani, T. M. (2013). Thematising Multilingualism in the Media. Amsterdam: Benjamins. https://doi.org/10.1075/bct.49

Mautner, G. (2008). Analyzing newspapers, magazines and other print media. In R. Wodak \& M. Krzyżanowski (Eds.), Qualitative Discourse Analysis in the Social Sciences (pp. 30-53). New York: Palgrave MacMillan. https://doi.org/10.1007/978-1-137-04798-4_2

Merriam, S. B. (2009). Qualitative research: A guide to design and implementation. San Francisco: Wiley.

Riley, C. A. (2005). Disability and the media: Prescriptions for change. Hanover, NH: University Press of New England.

Van Dijk, T. (1997). Discourse as Structure and Process. London / Thousand Oaks / New Delhi:

Wodak, R. (2004). Critical discourse analysis. In C. Seale, G. Gobo, J. F. Gubrium, \& D. Silverman (Eds.), Qualitative research practice. (pp. 197-213). London: Sage. https://doi.org/10.4135/9781848608191.d17

\section{Appendix}

The complete speech delivered by the Prime Minister of Pakistan, Syed Yousuf Raza Gilani, on May 09, 2011 in the parliament can be studied on the following link:

https://www.globalresearch.ca/the-prime-minister-of-pakistan-s-speech-on-the-abbottabad-operation-and-death-o f-osama-bin-laden/24701

\section{Copyrights}

Copyright for this article is retained by the author(s), with first publication rights granted to the journal.

This is an open-access article distributed under the terms and conditions of the Creative Commons Attribution license (http://creativecommons.org/licenses/by/4.0/). 